\title{
COVID-19 PANDEMIC AND CRISIS MANAGEMENT IN THE REPUBLIC OF CROATIA
}

\section{Robert Mikac}

Fakultet političkih znanosti

Sveučilište u Zagrebu

E-mail: rmikac@fpzg.hr
DOI: 10.20901/an.17.02

Review article

Accepted: November 2020

\begin{abstract}
The COVID-19 pandemic and the crisis that has affected all parts of the world, all industries and business processes, have significantly changed the usual way of life, introduced society to the 'new normal' and imposed the need for crisis management. Many organizations and countries were not ready for the crisis and consequently are suffering great consequences. The aim of this paper is to analyze how Croatia responded to this crisis from the aspect of the existing normative framework for crisis management and the operational solutions in practice, as well as to explore the role of the Government of the Republic of Croatia and its leaders in strategic decision making and interpretation of the crisis, and the extent to which homeland security and civil protection systems were put in function in managing the crisis. As an additional aim, the paper intends to mark a certain number of contradictions, controversies and paradoxes that arose during the crisis, as well as certain observations that can serve for further analysis and elements in the lessons learned process.
\end{abstract}

Keywords COVID-19 pandemic, Croatia, crisis management, homeland security system, civil protection system

\section{Introduction}

The coronavirus disease (SARS-CoV-2) and the COVID-19 pandemic originated in China in late 2019 and spread throughout the world through international travel causing immediate and immeasurable consequences. Coronavirus and the COVID-19 pandemic have caused a unique crisis in the entire human history because it literally affected the whole world, which has never happened before. Until this event, it was considered that only terrorism, confrontations of great powers and/or financial crises, such as the one that occurred in 2008, could cause major global disturbances which, in turn, could lead to widespread tectonic consequences. All other causes - including natural or man-made disasters or devastating wars (like the ones in Syria and Libya and before them those in Iraq and Afghanistan), had and were seen as having a limited regional character and did not have a real possibility of affecting the whole world. There are also other disruptive events such as global warming, climate change, habitat destruction and uncontrolled disposing of large quantities of waste into the environment that will eventually take their toll but so far these have been considered "creeping 
crises" for which the dynamic and busy world of today has no time. However, the world, governments, and international organizations cannot dismiss complex crises like COVID-19 (Mikac and Spevec 2020: 1-2).

Why is that so? How is it that a disease that has extremely low mortality has caused changes in life as we have known it? What is the cause of such high levels of fear in the actions of primarily states in dealing with the COVID-19 pandemic? This leads us to the first problem set of this research. Part of the answer lies in the amount of knowledge about the virus itself, in contradictory opinions, predictions and actions and in the ability of the international community to respond to such a challenge. Knowledge of the coronavirus was extremely limited at the beginning of the COVID-19 pandemic, but over time, scientists have been able to make significant advances in research and currently (mid-September 2020, when this paper was written) know much more about the virus itself (though still not enough) - the way it spreads and its consequences and, most importantly, about protection and self-protection. It is certainly necessary to emphasize fear as a psychological factor that played a significant role in the reaction of all actors - from states to the people. The positive aspect in this case is that the whole world is "united" in the search for a cure for coronavirus and for solutions to the crisis in which we find ourselves, but the negative is that the search for a cure has become a hurried pursuit for the Holy Grail with global pharmaceutical companies and most developed countries as the main competitors. That leads us to a contradiction that could be explained as simultaneous claims and negations of the same thing in the opinions, predictions and actions of global actors: US official policy at the beginning of the global cri- sis (first quarter of 2020) blamed China for the spread of the virus, accusing that country of artificially creating it, of not warning the world on time about the (possible) consequences, and then went on to accuse the World Health Organization (WHO) of favoring China, of not predicting events on time, of not acting appropriately and of not managing the crisis well. On these accusations, China and the WHO defended themselves by denying such claims. While the "big ones" were arguing, paraphrasing the old adage When America sneezes, the whole world catches a cold, time passed, there was no global reaction, but regional organizations and states acted by combining different approaches: from initial inaction (a state of standstill or complete passivity), as was the case in the European Union, through the balancing in Sweden, which opted for moderate security measures, down to the complete absence of balance and the bandwagoning - which Rendall L. Schweller (1994) explains as distancing oneself from current threats in order to maintain the status quo - which the vast majority of countries around the world have done by introducing the lockdown. From this follows the assumption about the ability of the international community to respond to the challenge it has faced. Ability could be explained as the fact or skill of being able to use the existing possibilities that determines the level of success in performing an activity. Here the role of the international and global community will be emphasized, because the development of the crisis soon took on a global character but the global response was absent, and consequently the states were forced to manage the effects of the crisis on their own. The global international community and international organizations (both the global ones like the WHO and the regional ones like the European Union) have shown an inability and unprepared- 
ness to adequately respond to the initial challenge of coronavirus, the COVID-19 pandemic and the emerging crises, which has after a long time put the states back into the spotlight as the key actors in international relations and the main protagonists in dealing with this crisis and consequently caused numerous contradictions, controversies and paradoxes.

Contradictions, controversies and paradoxes have characterized the world from its genesis to the present day. Every social activity is marked by statements or phrases that assert or imply both the truth and falsity of something (contradictions), discussions marked especially by the expression of opposing views (controversy), and statements that are seemingly contradictory or opposed to common sense and yet are perhaps true (paradoxes). All of the above are integral parts of crisis management at all levels and in all situations, and represent initial assumptions in the discussion on this topic. This represents the next problem set of this research. The greater the crisis, the more expressed are the features that accompany it. These are also "legitimacy" issues within the social sciences, politics, and everyday human interaction: in all processes where different experiences, views and interests exist, attitudes about the causes and consequences, what needs to be done and how, by what means and by whose responsibility will inevitably differ. This is further emphasized in areas with no clear competencies, detailed procedures and well-established mechanisms for implementing certain activities: in such situations we are often guided by a personal approach and preferences. All of the above is part of the discussion on the COVID-19 pandemic and how to react to the crisis. This crisis, as already mentioned, is unique in human history, it is extremely interdisciplinary and multi-layered with great current and even greater long-term consequences, it has affected all segments of society and all industries and businesses around the world. In the absence of the necessary global, interdisciplinary and systematic response there have inevitably been numerous contradictions, controversies and paradoxes when it comes to the crisis management process itself.

Everything stated so far serves as an introduction to setting the concept of this research. The main focus of this research is the impact of the COVID-19 pandemic on countries as primary actors in responding to the crisis, primarily on the Republic of Croatia and its ability to manage the crisis. The aim of the research is to look at the key aspects of crisis management and to record a number of observations that can serve as a basis for creating the first identified and then learned lessons for the next crises that we as a society and the state will face. The central research question is explanatory in nature and shall be used for discovering the connection between the normative basis and the practice in crisis management, for investigating the causes and reasons behind certain actions and for explaining the social phenomenon of crisis management. The research question is: How is Croatia managing the crisis in which it finds itself? The expected result of the research is the contribution to the debate from an academic point of view on how and with what capabilities the Republic of Croatia has managed this complex crisis.

In order to structure the research, the text will be divided into five additional sections after the Introduction. The second chapter, Theoretical and Methodological Framework, will provide an overview of the research methodology. The third chapter, entitled The Normative Approach to Crisis Management in the Republic of Croatia, will present the Croatian normative framework for cri- 
sis management, which provides a basis for discussing how Croatia has reacted in the current crisis. The next chapter, Croatian COVID-19 Pandemic Crisis Management, will give an analysis of crisis management compared to the normative framework. In the chapter entitled Discussion, the aim is to compare normative solutions with current practice and to note a number of observations that might in further analyses provide a basis for identifying and learning lessons. The last chapter, also the Conclusion, will provide a summary of the research and a review of the total collected material and the results of the analysis.

\section{Theoretical and Methodological Framework}

The crisis we are currently experiencing is extremely complex and interdisciplinary, and its observation and analysis can be approached from a multitude of different perspectives. While crisis management has been studied as part of security studies, economics, and management studies, for this purpose the classic discipline of crisis management will be used as part of security studies that has its own special vocabulary and concepts. In crisis management analysis, a framework consisting of four phases is most commonly and globally used: prevention, preparedness, response, and recovery. Each phase of the cycle has its own principles. Prevention refers to the measures, actions and activities taken to prevent the occurrence of harmful events. Preparedness means the establishment of all forms of cooperation and coordination of different actors in dealing with potential risks that have the capacity to grow into a crisis. Response is a reaction to the occurrence that caused a crisis situation and is carried out with the aim of mitigating and repairing the consequences. Recovery is an effort to return to the original state before the crisis broke out.

Furthermore, the key terms and concepts are considered and used in accordance with the following statements. According to Ole Holsti, there are four reference levels of crisis analysis: the state, the bureaucratic organization, society and the individual (Kešetović et al. 2013: 29). As already mentioned, the focus is on the state level, since its activities influence reactions at all other levels. Croatia defines a crisis as: "an event or state that endangers national security, the health and life of citizens, significantly damages the environment or causes significant economic damage, and the response to such an event or state requires coordinated action by several state bodies and coordinated application of measures within the competence of those bodies" (Croatian Parliament 2017a: Article 3, paragraph 2). On the other hand, crisis management is: a) the ability of the observed actor to prepare for crisis events by developing a rapid and effective response when a crisis occurs as well as effective crisis management (Kešetović and Toth 2012); b) the implementation of strategic decisions that include activities related to action within all phases of crisis management (Boin et al. 2010: 18).

The approach developed by Arjen Boin, Paul 't Hart, Eric Stern and Bengt Sundelius regarding crisis management policy in political systems will be used as a theoretical framework for the analysis. The authors consider that "crises have an essentially political character" (2010: 7), subjective nature and start entering the agenda of politicians "when policy makers feel threatened by the basic structure or fundamental values and norms of a system which under the pressure of time and highly uncertain circumstances requires vital decisions to be made" (2010: 12). Threats can have different initial causes, but the cause of 
the crisis in the political spectrum lies in the inability of the system to control the disturbances. The authors have developed a theoretical framework that involves five critical tasks for crisis management: observation, decision-making, interpretation, completion and learning (2010: 20) from which the parts related to decision-making and interpretation of crisis management will be used in this research. Decision-making is a key part of the spectrum of crisis response, which also includes the institutional context in which decisions are made and implemented, while interpretation is the transformation of a multitude of data into a coherent situational picture, informing different groups of the public and explaining decisions and actions.

Decision-making has, among other things, complicated characteristics because: a) it confronts political leaders with great uncertainties about the nature of the problem, the likelihood of future development and the possible consequences of different policy options; b) decisions must be made relatively quickly, under time pressure, which means that some of the tried and tested methods of the decision-making process cannot be applied. This puts politicians in an unenviable position because each of them expects a signpost, and in a crisis it is very difficult to provide that (2010: 46). As a rule, decision-making in crises takes place in small groups where political and bureaucratic leaders reach a kind of joint decision (2010: 48). The characteristics of the crisis, especially in its early stages, make central coordination and decision-making on the one hand more than desirable, while on the other hand almost unattainable. Therefore, each state, in accordance with the normative framework and previous practice, decides on a certain level of decentralization and improvisation (2010: 53-61). Finally, it is necessary to men- tion the role leaders have in responding to the crisis. "Leaders are important not as omnipotent decision makers but as creators, supporters and guardians of an institutional arrangement that leads to a process of successful decision-making and coordination" (2010: 65).

In terms of the interpretation of the crisis, "the crisis creates a context of basic ambiguities, confusion and speculation, conflicting beliefs, and collective awakenings. In these circumstances, it is important and extremely difficult for politicians to shape the process of social and political interpretation by which crises are named, understood and assessed - not only by what they are, but by what they tell us about social and institutional circumstances" (2010: 84). In times of crisis it is not uncommon for governments to "lose control, at least temporarily, over the drama of political communication. Events literally overwhelm them" (2010: 67). Therefore, political leaders along with other actors try to reduce the public and political uncertainty and stress caused by the crisis. They do that by constantly communicating, presenting data, explaining causes and consequences, and introducing their own political and personal credibility as they interpret the crisis. This theoretical framework is outlined in the previous three paragraphs, and will be applied when analyzing how the crisis has been managed in Croatia.

This paper presents a combination of results and findings: a) qualitative desk top research of primary and secondary sources in which methods of analysis and synthesis, induction and deduction are used; b) interviews with actors directly involved in crisis response activities working at the level of middle and senior management of public administration and the business sector; c) interviews with a focus group composed of members of the civil protection unit 
who were engaged in operational tasks during the crisis; d) own knowledge of the functioning of state systems primarily through the perspective of the Commander of Civil Protection of Croatia and Deputy Chief of the Civil Protection Headquarters of the Republic of Croatia from 2012 to 2015.

\section{The Normative Approach to Crisis Management in the Republic of Croatia}

The Republic of Croatia and its citizens have faced serious crises several times since the country became independent. The entire Homeland War (1991-1995) was one huge crisis, the consequences of which are still visible today. In recent times, various crises have somehow become frequent and have had a large impact on the country and the people. "The Kornati tragedy" was a major accident that took place in 2007 when 12 firefighters lost their lives during an intervention on the Veliki Kornat island. All the interconnected details between cause and effect have not yet been determined, making a detailed investigation of the crisis impossible and missing the opportunity to learn the maximum of lessons. The threat of major floods has become constant over the past decade. Precisely due to the consequences of the great floods in 2014 in the eastern part of the country, the Government of the Republic of Croatia declared a catastrophe for the area of the Vukovar-Srijem County (Government of the Republic of Croatia 2014). A year later Croatia, same as all other countries in Southeast Europe, faced a migrant-refugee crisis and participated in the relocation of more than a million people from Greece to Western Europe. By the end of the crisis in April 2016, more than 660,000 people had passed through Croatia (Croatian Institute of Public Health, 2017). In both cases, the civil protection system was the central platform of coordination that served as the backbone of the state's reaction by linking all other systems and actors in response to crises. In addition, there were occasional major or minor crises (fires, floods, adverse weather conditions due to snow and ice, swine flu, cyber attacks, etc.). This was the case until the first half of 2020 when the country suddenly became simultaneously exposed to several different types of crises: it started presiding over the Council of the European Union for the first time at the moment when the Union was in a deep structural crisis, with Britain withdrawing from full membership and Turkish president Recep Tayyip Erdogan threatening and pushing refugees and migrants towards Europe; several strategic state-owned companies (such as INA - a strategic oil company) were under strong cyber attacks; the global crisis caused by the COVID-19 pandemic began; on March $22^{\text {nd }}$ a strong earthquake hit the country's capital, Zagreb, and its surroundings (Mikac 2020). Faced with the above-mentioned crises, one cannot but wonder about the normative-institutional framework through which the country or its competent institutions manage such diverse crises.

Since the end of the Homeland War, the development of the normative framework for crisis management has gone into several directions. Each system (internal security system, security-intelligence system, defense system, civil protection system, health system and others) developed its own procedures and proceedings for managing and dealing with crises. In this analysis, the focus will be on the concept of building an integrated crisis management system that includes and coordinates several different systems because each complex crisis has multiple effects within different areas. The first guidelines for the 
development of public policies for the establishment of such a unified system in Croatia were given in the National Security Strategy of 2002, which indicated that a modern system of civil-military crisis planning and management would be organized by combining different parts of the system currently deployed in a number of ministries (Croatian Parliament 2002: paragraph 94). Afterwards, a similar approach was applied in the strategies that followed (National Strategy for the Prevention and Suppression of Terrorism of 2008 and 2015; National Strategy and Action Plan to Combat the Proliferation of Weapons of Mass Destruction of 2013; National Strategy for Cyber Security and the Action Plan for its Implementation of 2015), since there was a need to build a unified crisis management system. However, implementation did not take place immediately after the adoption of these strategies.

The next attempt to establish a unified crisis management system was related to the adoption of the 2017 National Security Strategy. The Strategy highlights separate crisis management systems, but also emphasizes the need to develop and establish an integrated system that would unite all existing systems into a single whole. It is stated that: "Experience to date in responding to emergencies suggests the need to establish a model that will systematically address identified shortcomings by ensuring coordinated planning, response and management in emergencies and crises. The goal is to achieve a synergistic preventive effect of several factors, quickly and effectively prevent or eliminate the harmful consequences of an emergency or crisis event and shorten the recovery time and return to functionality before the crisis event" (Croatian Parliament 2017b: Chapter IV, point A). For the implementation platform, it was decided that it would be a homeland security system, which had yet to be established. ${ }^{1}$ "Organizing the homeland security system will ensure the rational, efficient and harmonized use of existing resources in order to reduce or eliminate risks to national security. The homeland security system will support emergency and crisis management, which will include participation in crisis management at NATO and European Union level. The operation of the homeland security system will ensure a unique methodology and systematic monitoring of risks to national security and the determination of priorities in action" (Croatian Parliament 2017b: Chapter IV, point A). In order to harmonize the work of the homeland security system, it was decided that the Coordination of the homeland security system would be established. "In cases of emergency and crisis, the Coordination of the homeland security system shall propose to the Government of the Republic of Croatia and the President of the Republic of Croatia appropriate ways to respond and operationally coordinate state bodies involved in the operational response to the crisis" (Croatian Parliament 2017b: Chapter IV, point A).

\footnotetext{
1 As a basic difference between the national security system and the homeland security system, we can point out the spectrum of security risks that the systems in question deal with. The national security system is in charge of analyzing and acting on security risks that are primarily directed towards the activities of the state and its institutions, while the homeland security system expands the analysis and action towards all security risks that pose a danger to citizens, the environment, critical infrastructure and sustainable development. Thus, by introducing the homeland security system, Croatia has upgraded and expanded the area of dealing with security risks and included a larger number of actors and institutions that are not all part of state institutions, as was the case with the national security system.
} 
The operationalization of public policy guidelines related to the establishment of the homeland security system began with the adoption of the Homeland Security System Act a few months after the adoption of the Strategy. The Act, for the first time in Croatia, presented a definition of a crisis (mentioned earlier in the text) in an official document. The concept of a crisis and its definition were studies by a number of Croatian academic authors even before this official definition from 2017, but those definitions did not oblige State authorities to act upon them. According to its basic provisions, the Act "establishes a system of homeland security for the purpose of systematic management of security risks relevant to national security and crisis management" (Croatian Parliament 2017a: Article 1, paragraph 1) and "regulates the coordinated action of the body of the homeland security system and the implementation of activities and tasks within the competence of the body of the homeland security system arising from this Act, relating to security risk management and crisis management" (Croatian Parliament 2017a: Article 1, paragraph 2). Furthermore, the Act foresees the $\mathrm{Na}$ tional Security Council as the central body of the homeland security system and prescribes the obligations of the Coordination for the homeland security system. It also describes how crises shall be coordinated: "In case of a gradual or sudden crisis, which poses a risk to national security, the Coordination for the homeland security system shall propose to the Government of the Republic of Croatia to declare a crisis, form crisis management headquarters and ways to respond to the crisis" (Croatian Parliament 2017a: Article 10, paragraph 2).

Since then, the Coordination for the homeland security system has become operational, initial annual work plans have been adopted and approved by the National Security Council, and one of the goals for 2019 was to develop standard operating procedures and manuals for emergency and crisis management (the Office of the National Security Council 2018). Part of the professional and academic public, who follow and are particularly interested in the subject matter, felt satisfaction at the fact that the process of establishing a crisis management system has finally been launched with the aim of linking and coordinating the fragmented capabilities of different actors before and during crises. Further in the analysis, there will be an overview of how Croatia reacted in this crisis.

\section{Croatian COVID-19 Pandemic Crisis Management}

The test of the effectiveness of previous efforts in building a functional crisis management system came in early 2020 , when Croatia faced several different and very demanding crises at the same time (mentioned earlier). Throughout the crises, a significant number of different institutions and individuals have been engaged and great political, organizational and physical efforts have been made to manage them and mitigate their consequences in best way possible. It should be noted that at no time was there a risk of collapse of any system, of the institutions or of the political decision-making process, which would have lead to an even greater crisis. However, emphasis should at this point in time be placed on "what could have been done better", because there have been situations that could have been dealt with faster and more efficiently, such as clearing the earthquake debris in Zagreb and the six months that it took to pass a law on repairing the damage caused by the earthquake. Another issue identified during this period is a general lack of awareness how this 
affects the coordination of actions. For example, when strategic state-owned companies were under cyber attacks, some of them failed to report this (out of a desire to protect their brand, reputation and company market value), thus making it impossible for the competent law enforcement institutions to investigate all cases in detail and coordinate the response to attacks. These examples, as well as some other issues observed during the parallel crises of early 2020, serve to show that the field of crisis management as a discipline and an approach to crises is itself marked by crises in theoretical, normative and operational knowledge and activities - who, what, when, how and why should do something.

Focusing on the central theme of this research, the COVID-19 pandemic and crisis management, in relation to prevention (the first phase of the crisis management cycle) Croatia has recognized the risks of epidemics and pandemics. These have been identified and analyzed in the 2015 and 2019 Disaster Risk Assessment for the Republic of Croatia. Both documents state that pandemics are the kind of danger that can spiral out of control and turn into an event of catastrophic proportions. In the documents, the flu virus and the ensuing pandemic were considered and the description of the scenario envisages the exact same course of events that we have witnessed - the virus developed in Asia, from where it spread to Europe through international travel, and thus to Croatia (Government of the Republic of Croatia 2015; Government of the Republic of Croatia 2019). It predicts that in the most likely adverse event "the epidemic could last at least 9 weeks. Influenza and its complications kill 860 people in 9 weeks (mortality of $0.01 \%$ )." On the other hand, the prediction for the worstcase scenario was that "in 9 weeks, a to- tal of 2,580 of all infected persons would die (mortality of $0.2 \%$ )" (Government of the Republic of Croatia 2019: 41). Now, six months into the COVID-19 pandemic, it can be seen that we are far from these figures - the number of infected is around 17,000 and the number of deaths is below 300. Also, concerning prevention, it is necessary to point out another detail from the National Security Strategy from 2017, which states that "an integrated health system, accessible to all citizens of the Republic of Croatia, will continue to develop prevention measures and capacity building in public health aimed at preventing infectious diseases and mass non-infectious diseases" (Croatian Parliament 2017b: Chapter IV, point B). In terms of this part it can be pointed out that Croatia recognizes the risks of epidemics and pandemics and has established institutions and procedures to provide the necessary response, whereby the ability and effectiveness of the reaction significantly depend on the speed and manner of virus spread, virus type, time of year and additional factors.

Regarding the transition from prevention to preparedness phase (the second phase of the crisis management cycle), Croatia and its institutions actively monitored developments related to the coronavirus situation in China and the spread of the COVID-19 pandemic. The Croatian Institute of Public Health (the leading institution of the health system responsible for the development of public policies and guidelines for public health and in this case, the rules of conduct in the period before, during and after epidemics and pandemics) has been active developing and publishing quality materials, guidelines and instructions on the basis of which all competent bodies and citizens acted. Thus, in the prevention phase and the initial part of the preparedness phase, significant 
work was done to minimize the consequences of a potential crisis, because with the development of the situation in our environment it was obvious that the question is not whether the crisis will happen, but when and how ready we will be. The preparedness phase began with the activation of the Crisis Headquarters of the Ministry of Health at the end of January and the Civil Protection Headquarters of the Republic of Croatia in mid-February. The timely activation of these two headquarters enabled the necessary preparations for the crisis ahead. Every crisis carries uncertainties, time pressures and concern about how ready we are to react. In this phase, of the many open questions, two in particular should be singled out. First, how much protective equipment did the country have? Second, what about the activation of the homeland security system that is the law defines as the national crisis management platform? In terms of protective equipment, it was obvious that no country had sufficient amounts of protective equipment, which is understandable because of the cost, storage and maintenance issues related to equipment that might never be used. Croatia initially had some protective equipment in stock, but then went on to work on intensive procurement (receiving donations, purchasing, starting its own production). This was an appropriate reaction and answer to the issue. The answer to the second question related to the activation of the homeland security system in the preparedness phase was missing and it was not possible to understand why the Government did not activate this system. We had to wait for the reaction phase for indications of an answer.

For Croatia, the reaction phase began on February $25^{\text {th }}$, when the first infected person was registered in Croatia. After that, numerous activities to deal with the crisis and its consequences took place on a daily basis. Regarding the international perspective of the initial response to the crisis, numerous aspects and situations described in various studies have been confirmed: International organizations either lack the power - such as World Health Organization, which works according to the principle of recommendations - or are again caught by surprise with the situation and react quite late, like the European Union (Mikac 2020: 5). Here it is necessary to single out two opinions that speak of the difficult situation at the beginning of the reaction to the crisis. First, the European Union has been late in responding to the crisis and is therefore forced to engage in ad hoc reactive measures and activities. Political leaders "underestimated" the magnitude of the danger posed by the coronavirus, as the president of the European Commission Ursula von der Leyen admitted: "I think that all of us who are not experts initially underestimated the coronavirus" (Bild 2020). Second, regarding the direct consequences of the crisis on human losses, Slovenian infectious disease specialist Andrej Trampuž believes that "the World Health Organization and the European Union (when it comes to Europe) are most responsible for the coronavirus pandemic in which a huge number of people died." Neither of them reacted in time, or rather their reaction was very belated. He states that the virus arrived from China to Italy and then spread from Italy throughout Europe, while "the Italians are not to blame for what happened to them. They are the victims of misjudgments by the WHO and the EU. They should have sent all possible medical and scientific assistance to Italy. They should have sent virologists, infectious disease specialists, epidemiologists and all the necessary equipment, in order to create a true quarantine in Italy and prevent further spread of the virus. However, the 
WHO and the EU did not do that and they failed the exam. They did not do so because of economic lobbies, which pressured for the European borders not to close to avoid possible profit losses" (Marković 2020). The state of delay, incomprehension, lack of solidarity, closing of borders led each country to turn to itself and work on its own vision and crisis management skills. This is the context in which Croatia entered the response phase to the COVID-19 pandemic.

The executive authority decided that the response to the crisis would be based on the "Whole-of-Government" approach, with the civil protection system as the central framework of Croatia's response to the crisis. The system itself has been activated to the full of its capabilities and available capacities. At state level, the Civil Protection Headquarters of the Republic of Croatia have become the place for making strategic responses and from where all key activities are directed. The Civil Protection Directorate of the Ministry of the Interior determined all administrative, logistical, communication and coordination tasks for the needs of the Headquarters and the system as a whole, as well as cooperation with all institutions from the public and private sector. All regional and local civil protection commands have been activated, each carrying out activities and instructions from the state level in their area of responsibility. Alongside with the civil protection system, the entire health system - from the Ministry of Health, the Crisis Headquarters of the Ministry of Health, the Croatian Institute of Public Health, all health facilities and staff - were active and selflessly engaged to the maximum "from day zero" (Kranjčević 2020: 12). With them, many other systems and subsystems were engaged to a significant extent and contributed to the overall effort. All of them are still very actively involved because the crisis is ongoing.

The initial course of action was marked largely by a general lockdown, the slowing down and cessation of numerous economic and social activities, the introduction of restrictions on movement and recommendations on physical distancing. According to research conducted by Oxford University COVID-19 government response tracker, at one time during March 2020 Croatia was the country that took the most restrictive measures (Večernji.hr 2020a). The Government established a Scientific Council (which includes a number of top Croatian medical/health scientists) with the aim of exchanging opinions on measures to be taken in combating the epidemic, assessing the situation and making recommendations for further action (tportal.hr 2020a). The Council and its members were very active in the months that followed. A public survey conducted at the end of March by Dnevnik Nova TV showed that $94 \%$ of the respondents supported the Government in the implementation of public health measures, and $63 \%$ thought that our measures were better than in the rest of the EU (Telegram 2020). The Civil Protection Headquarters of the Republic of Croatia met daily, tirelessly communicated with all groups of the interested public and directed the national crisis response. Therefore, it can be said that at the beginning of the crisis, while faced with a number of difficulties, Croatia reacted quite well in the health and security segment, while in some other areas such as financial management, economy and tourism, we cannot be satisfied with the initial reaction of the competent institutions. Moreover, this crisis has shown that the above sectors do not have crisis plans and that their leaders are not adequately trained in crisis management, which is why they are 
having difficulties or hardly adjusting to functional operation in a state of crisis. Also, most business owners expect ready-made solutions and assistance from the state, and only a small number of them have the readiness and ability to cope with the crisis (Mikac 2020: 6). In this regard, there have been some initiatives for the establishment of a Crisis Headquarters for the economy (Crisis Economic Council of the Government of the Republic of Croatia) which would include representatives of the public, the real and the scientific sectors to advise the Government on the best possible crisis solutions. However, according to publicly available sources of information, it is not possible to determine whether such headquarters/council has been established and, if so, whether it is operational. In other words, the beginning of the crisis was marked by confusion in the sectors of finance, economy and tourism, which could be reduced to a common denominator as "Government measures for the economy show that they are completely lost in the crisis" (Vuković 2020a). No one remembered to propose, and the Government did not seem to deem necessary, the establishment of a Crisis Management Council, which would advise the Government on the necessary interdisciplinary crisis measures and which of all of the advisory bodies would be the most necessary one. To conclude this section, the first part of the crisis was characterized by a very good reaction in health and security, great disorientation in finance, economy and tourism and a very clumsy statement by Prime Minister Andrej Plenković that Croatia is at war with coronavirus, at war with panic and at war with economic consequences of the pandemic (Nacional 2020a). With that statement, he unnecessarily militarized the vocabulary of the crisis and instead of calming the situation only contributed even more to the panic.
Following the consolidation of the condition in all sectors, the continuation of crisis management was marked by a significant easing of lockdown measures, a gradual reopening of the borders and greater freedom of movement. Recommendations regarding protection measures, self-protection and physical distancing remained in force. During that time - between April and June - the Government faced two major challenges. The first was to coordinate the implementation of epidemiological measures and organize parliamentary election (held on 5 July). The other, to determine whether to "open the country up" in anticipation of the tourist season and to what extent. Regarding the first challenge, with the active preparation of all realistically feasible scenarios and possibilities, this period is marked by the beginning of stronger political influence on analyses, assessments and recommendations of the Civil Protection Headquarters, which ultimately resulted in a statement by the Health Minister, Vili Beroš, (mid-September) that the Headquarters are a political body, but that none of their decisions were politically motivated (Jutarnji.hr 2020). Very inconvenient and very untoward. When it is said that the Headquarters are a political body (and the essence of politics is the struggle for power, influence and positions), the essence of the message sent is understood quite differently by different people. Certain decisions that the Headquarters began to make from April to June had, to a lesser or a greater extent, a political background and connotation (permission to hold a church procession on the island of Hvar on April $10^{\text {th }}$ when the whole country was in lockdown, the Sunday work ban, allowing masses to be held while all other gatherings were banned, the re-opening of the borders with Bosnia and Herzegovina due to elections, etc.) and that is best reflected in the results of monthly 
polls on the popularity of public figures on the case of Beroš. From April to September "Berošs drop in ratings became a phenomenon; that man slipped from 30 to 3 percent in 6 months" (Frlan Gašparović 2020). In addition to the above, the Headquarters and the civil protection system continued to do their best and were able to manage the crisis with the support of all other institutions involved. During this time, the finance, economy and tourism sectors began to keep pace with developments, the Government made significant progress compared to the initial situation, so that in these sectors most activities looked much better than at the beginning of the reaction (but was that good enough?). As the whole situation gradually consolidated and Croatia started recording days without no infected persons, Plenković once again needed to make a bombastic statement, this time at the end of May, saying that Croatia had defeated COVID-19, that the Government had defeated COVID-19, that we had overcome the epidemic and that at the economic and social level the epidemic was also defeated (Nacional 2020b). Purely political and too premature.

Regarding the second challenge, whether to reopen the country for the upcoming tourist season and to what extent, the Government opted for a "calculated risk" and that is why the tourist season was better than expected, as Plenković stated. "We have achieved this by opening up on time, by applying the calculated risk approach, and everything that was not completely shut down posed a risk. However, this was not accidental but based on consultations with prominent scientists who said this spring, not just based on observing past pandemics but based on attempts to predict what will happen during the summer months, that the character of the virus did not change; it is just that the people's resilience to the virus is higher during the summer months. This allowed us to have a much better tourist season than expected, and in that regard, we rank at the very top when compared with our competitors from the European Union and the Mediterranean. So that was a good, wise, justified move and we would repeat it if we found ourselves in another situation of that kind" (Večernji.hr 2020b).

In the summer began the third part of the reaction to the crisis, described by scientist Ivan Đikić in the following way: "the Headquarters were set up as a political body, but in the beginning, out of fear, the Headquarters implemented perhaps 100 percent professional measures in their work. And then the Headquarters started being perceived as an expert body and all the scientists of the world supported such an attitude of the Headquarters. But the moment political pressure to open the borders with Bosnia and Herzegovina started, partly because of the election, and the pressure to engage in aggressive tourism promotion as if that was our only salvation, or when it was said that the virus had weakened, and that came from Minister Beroš, it became immediately obvious that by doing so the Headquarters were making increasingly politically motivated decisions, less and less motivated by expert data. And this caused the majority of citizens to lose trust in them. That is why today the citizens no longer believe that they are a body of experts" (tportal.hr 2020b). During the tourist season, the impression was that the financial, economic and tourism sectors had started to do their job more efficiently and together with diplomacy (of course, with the constant support of the health profession) worked very well in different markets and communicated daily with many domestic and international actors. During that time, the civil 
protection system was still working on already well-established tasks, but the end of the summer showed that it was slowing down and losing pace with the development of events, and that events were happening faster than it could respond to them. Since what has just been described is also the current situation (at the moment when this paper was being written), the following analysis will determine what the reason behind that is.

In conclusion to this part, one needs to ask what happened to the homeland security system and its role in crisis management? Official information is very scanty. On March $5^{\text {th }}, 2020$, a session of the National Security Council (the central body of the homeland security system in accordance with the Homeland Security System Act) was held. The session was jointly convened by the President of the Republic of Croatia Zoran Milanović and the Prime Minister Andrej Plenković. "Members of the Government and the Civil Protection Headquarters of the Republic of Croatia reported on all activities undertaken in the past two months related to the suppression of the coronavirus (Covid 19) epidemic at both national and EU level, given the fact that Croatia is currently presiding over the Council of the European Union. It was concluded that all measures taken so far have been timely, effective and transparent. In addition to all activities related to health and security, possible consequences for finance, tourism and the economy were analyzed. Following the discussion, it was concluded that all competent institutions should continue to take additional measures in accordance with the needs, including regular meetings of the European Union Health Council" (Office of the National Security Council 2020). The Coordination for the homeland security system held a session on April $8^{\text {th }}$ (the reaction to the crisis began on February $25^{\text {th }}$, and the coronavirus epidemic was declared March $12^{\text {th }}$ ) at which Plenković expressed that "the system [of homeland security] works well through the national Civil Protection Headquarters, which was established in a timely manner and which takes appropriate measures in the fight against coronavirus, as well as through the lightning reactions of all services after the earthquake in Zagreb a few weeks ago, which did everything to ensure the security of citizens, clean the city and all other things that followed - from preparations for repairing the damage, through drafting the laws, to finding the sources of financing for the reconstruction of the city" (Government of the Republic of Croatia 2020). After this, information on the activities of the National Security Council and of the Coordination for the homeland security system was no longer publicly available, so this part of analysis will be concluded.

\section{Discussion}

For the purposes of the discussion, it is necessary to specify the variables that determine its framework and content. Three of them will be used. First, it is much easier to be a critic of other people's thoughts, words and deeds than a creator of your own. Therefore, the authors have tried to express not a critique but their observations about certain activities, with the aim of indicating that there is a possibility, room and need for change. Second, the authors wished to avoid the trap of what Nassim Nicholas Taleb calls naive empiricism, that is, a "disgusting method of gathering selective corroborating evidence" that supports only one thesis (2009: 29). Third, as this crisis has caused numerous contradictions, controversies and paradoxes, certain opinions (of scientists, experts, chroniclers, politicians, entrepreneurs) were singled out to support the discussion on 
the model and manner of managing this crisis.

The discussion should be opened with two statements. First, that the Government did not use all available capabilities. It did not activate the homeland security system and/or the Coordination for the homeland security system as the central platform and actor of crisis management, although that would have been expected in accordance with the Homeland Security System Act. Likewise, the initial impulse for the activation of the system and the operation of the Coordination for the homeland security system did not come from the homeland security system itself. Earlier, it was stated that one session of the National Security Council was held (March 5th) as well as one session of the Coordination for the homeland security system (April 8th) with very brief statements on what was discussed and what the next activities would be. There may have been additional activities, but they are not available or visible to the average observer nor to the analyst, so it can be concluded that they did not take place. Second, it is important to point out that no crisis has ever been officially declared - although there is a clear definition of crisis in the Homeland Security System Act and there is a mechanism for proposing it to the Government. Therefore, it remains quite unclear to almost everyone why the crisis has not been declared. Was it not even suggested? Has the proposal to declare a crisis not been adopted by the Government? How does the process of proposing and declaring a crisis function in general? An additional challenge to the fact that the crisis has not been declared is that everyone has talked about it, we have obviously found ourselves in a crisis of all possible forms and values, and on the other hand, the Government has pointed out that we are at war. How can one be at war without being in crisis? These two examples alone shed light on the inconsistency between the existing normative framework of crisis management and its implementation in practice. It is important to reiterate (stated at the beginning of this section) that activating the homeland security system and the Coordination for the homeland security system as a platform and actor for crisis management is an opportunity and a capability that the Government did not use, but also one that it did not necessarily need. It would have been logical to use it but certainly the Government can decide on other options, which it did by activating the civil protection system and the Civil Protection Headquarters of the Republic of Croatia as the central elements for managing this crisis. Such a decision by the Government is its legitimate right, but it remained unexplained and confused all those who expected the homeland security system and the Coordination for the homeland security system to play a central role in crisis management. This is one of the reasons behind some of the contradictions, controversies and paradoxes that followed in the crisis management process.

In this part, some key messages from people who have political, business, social, scientific and journalistic credibility and/or influence will be singled out to point to the challenges of managing this crisis. These statements should be observed bearing in mind the time of their making. The first set of statements was made in April at the beginning of the crisis and refers to crisis management framework, content and manner. Observing the activities of the homeland security system, activist Gordan Bosanac believes that "the homeland security system has not disappeared. It simply never existed, and the COVID-19 pandemic (with the earthquake in Zagreb) revealed all the emptiness of 
the term 'homeland security"' (Bosanac 2020). Quite the opposite is the opinion of journalist Petra Kostanjšak from the magazine Hrvatski vojnik, who believes that the Croatian model of coordinated response to crises in the first phase successfully passed the extraordinary exam (Hrvatski vojnik 2020), while journalist Ivica Đikić from Novosti states that "due to the spread of the corona infection and the Zagreb earthquake, all the preconditions were created for Damir Krstičević and the famous "homeland security system" to enter the scene. However, Plenković believed that Davor Božinović was his only associate who could manage the crisis relatively calmly and professionally" (Đikić 2020). On the topic, security analyst Igor Tabak wrote in May that "in recent months it has not been difficult to see how Croatia has practically been experiencing a clash of two crisis management and response systems - the civil protection system and the homeland security system" (Tabak 2020). Back in April, scientist Vuk Vuković said that the crisis has revealed that Croatia has major problems in functioning during the crisis (Vuković 2020b), entrepreneur Nenad Bakić believed that Croatia had successfully managed the crisis thus far (Bakić 2020), and security expert Robert Barić that Croatia does not have a crisis management system but has been managing the current crisis with a series of improvisations (Barić 2020). Infectious disease specialist Vladimir Krajinović states that luck is the primary reason for Croatia's success in the fight against the coronavirus epidemic. "There are several reasons. Although many think that it is all due to the National Headquarters, I will say that it was primarily - luck. (...) Croatia was lucky that the virus first came to Italy, so we had time to "wake up" and prepare. The cases came one by one and we somehow managed to get organized. (...) The second reason are the isolation measures, and the Nation- al Headquarters did a pretty good job there. Personally, I think they should and could have been even faster with the closure measures. Many things were done reactively, and not proactively. (...) The third reason that helped us was possibly the fact that the virus did not enter the health system or nursing homes for a long time, as was the case, for example, with neighboring Slovenia. However, we now see that the virus entered nursing homes at a later stage and that does not favor of the Headquarters" (Krajnović 2020). Therefore, during April we witnessed very different statements that showed us that there are significantly different understandings and experiences of the framework, content and ways of managing the crisis.

The second set of opinions emerged during and after the summer. Tourism expert Veljko Ostojić stated that Croatia was sending confusing messages, and the competition was waiting for our mistake to take our guests (Koretić 2020). Scientist Ivan Đikić believed that "Croatia played a very good match from February to June. Every decision was made in such way that it was known what would happen in the next two weeks. Sometime in mid-June, when we declared that the coronavirus in Croatia was defeated, there was a relaxation, a misunderstanding of certain decisions, and poor communication and this, in turn, led to a loosening of public tension. People somehow began to understand that the virus was not so dangerous anymore, and now for the past month we have been faced with a relaxation, misunderstandings, and bad decisions" (tportal 2020c). Entrepreneur Branko Roglić thinks "that the Government has reacted extraordinarily so far, that it has taken everything necessary to maintain employment and keep the economy alive. The economy would simply not be able to survive on its own, 
without these measures that we are all expecting to benefit from. There would be layoffs and companies would go bankrupt" (Novi List 2020). At the same time, the Association of Entrepreneurs "Glas" and its executive director Dražen Oreščanin considered numerous decisions of the Government to be belated, discriminatory or an alibi for the poor functioning of the Headquarters (Novac.hr 2020; Glaspoduzetnika.hr 2020; N1 2020a). Concerning the work of the Civil Protection Headquarters, scientist and member of the Scientific Council of the Government Gordan Lauc claimed: "When we see how some other things work in this country, the Headquarters function fantastically. There were certainly mistakes and misunderstandings, some things could have been done better, but in the context of our state, I think that the Headquarters have done a solid job and that there is not that much that we can hold against them" (net.hr 2020). Another scientist and member of the Scientific Council of the Government, Dragan Primorac, also thinks that the Headquarters have been doing a good job, that the position of the members of the Headquarters is among the most ungrateful in Croatia and says that after months spent under stress there was a certain relaxation by everyone, which he considers natural and normal (Jutarnji.hr 2020b). President Zoran Milanović, on the other hand, believes that the Headquarters are a para-constitutional body, referring in particular to the decisions restricting movement, which the Headquarters proposed and introduced and which in his opinion are not within the competence of the Headquarters but of the Parliament (Liberoportal.hr 2020). At its session held on September $14^{\text {th }}, 2020$, the Constitutional Court of the Republic of Croatia ruled on the constitutionality of the decisions of the National Civil Protection Headquarters stating that the Headquarters did not violate anyone's constitutional rights by issuing a series of decisions, including movement restriction measures. Three judges, Andrej Abramović, Goran Selanec and Lovorka Kušan disagreed with the majority decision of their Constitutional Court colleagues and issued separate opinions on this topic (Raić Knežević 2020). This all serves to show that this is a sensitive issue on which no consensus of opinion has been reached even within the Constitutional Court. Milanović commented on the decisions as follows: "Certain human rights have been suspended and for quite some time. A very vague and loose legal framework has been adopted and the Constitutional Court is scared, but this is only human" (N1 2020b). Finally, it is not pretentious to conclude that each of the above mentioned sources in the previous and this chapter is right, though not entirely because everyone has experienced, analyzed and commented on the management of the crisis from their perspective, taking into account own previous experience and referring to their part of expertise. This points to a vast area that has opened up concerning the manner in which this crisis was managed, that needs to be researched, analyzed and documented in order to extract all possible observations, identify and learn lessons.

Everything mentioned thus far fits perfectly into the previously set theoretical framework for crisis analysis. In the part related to decision-making, everything that Croatian decision makers underwent corresponds to the theoretical pattern developed by Arjen Boin and coauthors. Decision-making, especially of a strategic nature, confronted Croatian political leaders with great uncertainties about the nature of the problem, the likelihood of future developments and the possible consequences of different policy options, where all decisions had 
to be made relatively quickly, under time pressure and without the possibility of theoretical verification of effects. All this has put them in a very unenviable position because and everyone expects leadership and solutions, and in a crisis it is very difficult to provide that. Decision-making was done in small groups with only few participating members of the Civil Protection Headquarters (other members of the Headquarters were not involved). As far as decentralization and improvisation are concerned, these have been applied to a significant extent. Management was decentralized and strategic decisions were delegated to regional and local commands of the civil protection system. While improvisation was pervasive (which is not necessarily bad management on its own) it is the Croatian reality in management, not only in crises but also in regular business. Finally, let us not forget the role of the leader. The only true political leader in this crisis was Prime Minister Andrej Plenković. Regardless of his awkward and/or premature statements, he did not interfere in the work of key bodies, did not convene press conferences to praise the results, or publicly influence the processes. Instead, every time when there was a vacuum, when at lower levels politicians got stranded and/or were stuck with challenges - he stepped forward and stabilized the political situation with his credibility.

This crisis can be interpreted as bringing about many ambiguities, confusion and speculation, conflicting beliefs, and collective awakenings. Therefore, it has been and still is extremely difficult for politicians to shape the process of social and political interpretation of the crisis. For this reason, their openness and availability to communicate primarily with the media on a daily basis should be saluted, but they should be criticized for not hiring crisis communication ex- perts and spokespersons (who would do it better than them, while they could focus on analysis and policy). Finally, it is important to point out that the government did not lose control over the temporary drama of political communication and, more importantly, over events - despite all the difficulties and improvisations.

The last part of this section is devoted to the insights gained through interviews with actors directly involved in crisis response activities, who worked at the level of middle and senior management of public administration and the business sector; interviews with a focus group composed of members of the civil protection unit who were engaged in operational tasks during the crisis; and own knowledge of the functioning of state systems gained primarily from the perspective of the Commander of Civil Protection of Croatia and Deputy Chief of the Civil Protection Headquarters of the Republic of Croatia from 2012 to 2015. This paragraph is also the shortest because the insight gained is mostly confirmed by what has previously been mentioned. Thus, the opinions of the respondents and the author's personal experience confirm the perception of how Croatia manages crises in general, and the current crisis: primarily by applying the "whole of Government" approach instead of an integrated crisis management system, where we rather rely on improvisation than set up the systems and play by the rules, where everyone does everything and therefore everyone exhausts their capacity, and where there is no inter-agency and interdisciplinary analysis after each action which means we enter the crisis every time from almost the same starting position.

\section{Conclusion}

The research conducted showed numerous open contradictions, contro- 
versies and paradoxes arising from the non-existence of a crisis management system that would clearly define the competencies, powers and responsibilities of all actors - from the Government to the citizens. Therefore, it can be concluded that the research concept as well as the theoretical and methodological framework have been well set in order to conduct this research. The topic is multifaceted, everyone observes and analyzes it from their own angle of expertise. For the purposes of this research, the authors decided to compare the connection between the normative basis and the practice in crisis management, to investigate the causes and reasons for certain actions, and to explain crisis management as a social phenomenon. This was done by means of an overview of the normative solutions and practices, the causes and reasons for certain actions and the social perspective of crisis management. A large part of the challenge of good crisis management at all levels, from the President of the country to the citizens, lies in the fact that Croatia does not have an adequately developed legislative framework and crisis management system, that existing normative solutions are not properly applied in practice, and that practice is not sufficiently harmonized with the existing legislative framework.

In answer to the main research question: How is Croatia managing the crisis in which it finds itself?, it can be said that Croatia is currently relatively successful in navigating this crisis and ranks at the level of most Western European countries, with which our governments always like to compare themselves - neither better nor worse. This only serves to show that the crisis was a big surprise for all countries, it is still ongoing and its outcome is still uncertain. From an analytical point of view, it is interesting to see that two countries considered to be global leaders (the USA and the UK) failed in crisis management (both in theory and in practice) during the first part of the crisis and therefore their population (and not the politicians responsible for such a condition) is now suffering severe consequences. For now, Croatia has managed to ensure that events do not overwhelm us, that we do not have large number of infected and deceased, that there are no significant disturbances in the functioning of the state and everyday life, and that the crisis does not cause domino effects that would create additional significant damage. On the other hand, the crisis has shown that Croatia in many areas was not ready or able to respond to the initial impact of the crisis, i.e. in the financial, economic and tourism sectors, and therefore our citizens (and not responsible politicians) will suffer the consequences. Operationally, Prime Minister Plenković decided to assign crisis management to Deputy Prime Minister and Minister of the Interior Davor Božinović in charge of civil protection, instead of Deputy Prime Minister Damir Krstičević and Minister of Defense in charge of homeland security. He thus determined that the civil protection system would be the platform through which Croatia would face the crisis, and reduced the chances for the homeland security system to establish itself. This was his decision and risk, which so far proves to be correct in terms of the ability of the civil protection system to coordinate and manage key processes. But as every crisis is also a good opportunity, this crisis was an ideal opportunity (it is now clear that it was a missed opportunity) to give the homeland security system and the Coordination of the homeland security system the responsibility to manage the crisis. This way, that system could have been established and finally become functional, and not pushed aside and exposed to criticism. 
One of the observations coming from this crisis which could help politicians, and indirectly all others, could be that it is necessary to finally regulate security systems, their cooperation and coordination, open a public-private partnership in the field of security and involve the scientific community in solving problems, so that everyone can contribute to setting the key priorities of this country in the field of security, and then work on smart specialization. As for the Republic of Croatia, in addition to lacking a unified crisis management system, it also lacks a unified assessment of the security risks it faces. That assessment had to be made immediately after the Homeland War, because without it all investments and actions were brought down to silo mentality - where everyone works and acts in a world of their own, with limited inter-sectoral cooperation. Once that assessment has been made, politicians involved in strategic decision-making need to be trained on crisis management, as at lower levels there is more knowledge and experience, both because of training opportunities throughout their careers and because of the actual operational experience. Therefore, currently there is an imbalance in knowledge between those who manage and those who are managed. And finally, although the actual list of observations is much longer, it is necessary to highlight the process of lessons learned which consists of making observations like these, identifying the lessons and ultimately learning them. This country has the knowledge and the experts capable of drawing observations from all situations, including crises like these, and synthesizing the identified lessons from them, but politics must refer to them and take their analyses and findings into consideration. Politicians have neither the practice nor the habit of doing cross-sectoral and interdisciplinary post-crisis analyses with crisis-involved operational forces, administrative experts, the private sector and the academia, in order to observe what really happened during the crisis. The main purpose of that would be to see what was good and what was not that good with the aim of improving the reaction to make it better, faster and more successful with less effort, cost and stress.

This research, its observations and results serve as an overview of the current state of Croatia's management of the current crisis. All of the above can primarily serve politicians to change systems for the better, because politics has networked our entire society and reality, it has entered every pore and activity, and without it nothing concrete can be done. 


\section{Bibliography}

Bakić, Nenad. 2020. Švedska dobro napreduje u borbi s koronom, Hrvatska je fantastična. Poslovni.hr. Date of publication 15.4.2020. Accessed 20. 9. 2020. https://www.poslovni.hr/ hrvatska/bakic-svedska-dobro-napreduje-u-borbi-s-koronom-hrvatska-je-fantasticna-4226331.

Barić, Robert. 2020. Hrvatski paradoks: improvizacija umjesto organiziranog sustava. Politička misao. Date of publication 17. 4. 2020. Accessed 3. 9. 2020. http://politickamisao.com/hrvatski-paradoks-improvizacija-umjesto-organiziranog-sustava/\#more-7940.

Bild. 2020. Wir alle, die keine Experten sind, haben das Virus unterschätzt. Date of publication 18.3.2020. Accessed 18.9.2020. https://www.bild.de/ politik/inland/politik-inland/coronavirus-von-der-leyen-wir-alle-die-nicht-experten-sind-haben-es-unterschaetz-69459290.bild.html.

Boin, Arjen, Hart, Polt, Stern, Eric, Sundelius, Bengt. 2010. Politika upravljanja krizama: Javno rukovođenje pod pritiskom. Beograd: Službeni glasnik.

Bosanac, Gordan. 2020. Kako je nestao sustav domoviske sigurnosti? Obris. org. Date of publication 8. 4. 2020. Accessed 22. 9. 2020. https://obris.org/ hrvatska/kamo-je-nestao-sustav-domovinske-sigurnosti/.

Croatian Institute of Public Health. 2017. CARE: Zajednički pristup zdravlju izbjeglica i drugih migranata. Accessed 24. 9. 2020. https://www.hzjz.hr/ sluzba-epidemiologija-zarazne-bolesti/care-zajednicki-pristup-zdravlju-izbjeglica-i-drugih-migranata/.

Croatian Parliament. 2017a. Zakon o sustavu domovinske sigurnosti. $\mathrm{Na}$ rodne novine br. 108/2017. Accessed 14. 9. 2020. https://narodne-novine. nn.hr/eli/ sluzbeni/ 2017/108/ 2489.
Croatian Parliament. 2017b. Strategija nacionalne sigurnosti Republike Hrvatske. Narodne novine br. 73/2017. Accessed 13. 9. 2020. https://narodne-novine.nn.hr /clanci /sluzbeni/ 2017_07_73_1772.html.

Croatian Parliament. 2002. Strategija nacionalne sigurnosti Republike Hrvatske. Narodne novine 32/2002. Accessed 15. 9. 2020. https://narodne-novine.nn.hr/eli/ sluzbeni/ 2002/32/692.

Đikić, Ivica. 2020. Portal Novosti: Rusvaj domovinske sigurnosti. Date of publication 26. 4. 2020. Accessed 19. 9. 2020. https://www.portalnovosti. com/rusvaj-domovinske-sigurnosti.

Frlan Gašparović, Irena. 2020. Berošev pad rejtinga sad je već fenomen; čovjek je u 6 mjeseci s 30 skliznuo na 3 posto. Telegram.hr. Date of publication 8. 9. 2020. Accessed 18. 9. 2020. https://www.telegram.hr/politika-kriminal/berosev-pad-rejtinga-sad-jevec-fenomen-covjek-je-u-6-mjesecis-30-skliznuo-na-3-posto/.

Glaspoduzetnika.hr. 2020. UGP upozorava: Hrvatska potpuno nespremna na turiste potencijalno pozitivne na COVID-19. Date of publication 22. 6. 2020. Accessed 19. 9. 2020. https:// www.glaspoduzetnika.hr/ugp-upozorava-hrvatska-potpuno-nespremnana-turiste-potencijalno-pozitivne-nacovid-19-n66.

Government of the Republic of Croatia. 2020. Sustav domovinske sigurnosti dobro je odgovorio na dvije paralelne krize - epidemiju korona virusa i potres u Zagrebu. Date of publication 8 . 4. 2020. Accessed 12. 9. 2020. https:// vlada.gov.hr/vijesti/sustav-domovinske-sigurnosti-dobro-je-odgovorio-na-dvije-paralelne-krize-epidemiju-korona-virusa-i-potres-u-zagrebu/29190. 
Government of the Republic of Croatia. 2019. Procjena rizika od katastrofa za područje Republike Hrvatske.

Government of the Republic of Croatia. 2015. Procjena rizika od katastrofa za područje Republike Hrvatske.

Government of the Republic of Croatia. 2014. Odluka o proglašenju katastrofe za područje Vukovarsko-srijemske županije. 161. telefonska sjednica Vlade Republike Hrvatske, 20. 5. 2014. Accessed 23. 9. 2020. https://vlada. gov.hr/sjednice/161-telefonska-sjednica-vlade-republike-hrvatske/11576.

Jutarnji.hr. 2020a. Beroš: 'Stožer je političko tijelo, ali niti jedna njegova odluka nije bila politički motivirana'. Date of publication 14. 9. 2020. Accessed 19. 9. 2020. https://www.jutarnji.hr/ vijesti/hrvatska/beros-stozer-je-politicko-tijelo-ali-niti-jedna-njegova-odluka-nije-bila-politicki-motivirana-15018969.

Jutarnji.hr. 2020b. 'Nema novog lockdowna, ali danas ne možemo tvrditi da će se pronaći učinkovito cjepivo؛ Date of publication 24. 8. 2020. Accessed 22. 9. 2020. https://www.jutarnji. hr/vijesti/hrvatska/nema-novog-lockdowna-ali-danas-ne-mozemo-tvrditi-da-ce-se-pronaci-ucinkovito-cjepivo-15015138.

Kešetović, Želimir, Korajlić, Nedžad, Toth, Ivan. 2013. Krizni menadžment. Sarajevo i Velika Gorica: Fakultet kriminalistike, kriminologije i sugurnosnih studija i Veleučilište Velika Gorica.

Kešetović, Želimir, Toth, Ivan. 2012. Problemi kriznog menadžmenta (Crisis management problems). Velika Gorica: University of Applied Sciences Velika Gorica

Krajnović, Vladimir. 2020. Hrvatska je imala sreće, za virus nismo bili spremni. Danica.hr. Date of publication 19. 4. 2020. Accessed 6. 9. 2020. https://danica.hr/dr-krajinovic-hrvatska-je-imala-srece-za-virus-nismo-bili-spremni/.

Kranjčević, Vedran. 2020. COVID-19: Case Study of the Republic of Croatia - Management of the Crisis from the Healthcare Authorities Perspective. In: RACVIAC Newsletter. Special edition, June 2020, pp. 11-13.

Koretić. Dora. 2020. Direktor HUT-a: Šaljemo zbunjujuće poruke, konkurencija čeka našu grešku da nam uzme goste. Date of publication 5. 7 . 2020. Accessed 21. 9. 2020. https:// novac.jutarnji.hr/restart-ideje/direktor-hut-a-saljemo-zbunjujuce-poruke-konkurencija-ceka-nasu-gresku-da-nam-uzme-goste/10418878/.

Kostanjšak, Petra. 2020. Sustav domovinske sigurnosti: Uspjeh hrvatskog modela odgovora na krize. Hrvatski vojnik online izdanje. Date of publication 30. 4. 2020. Accessed 20. 9. 2020. https://hrvatski-vojnik.hr/sustav-domovinske-sigurnosti-uspjeh-hrvatskog-modela-odgovora-na-krize/.

Liberoportal.hr. 2020. Milanović o Stožeru: To je paraustavno tijelo. Date of publication 26. 7. 2020. Accessed 12. 9. 2020. https://www.liberoportal.hr/ politika/covid-19-milanovic-o-stozeru-to-je-paraustavno-tijelo.

Marković, Ivica. 2020. 'Nemojmo se lagati, jako se dobro zna krivac za smrt desetke tisuća Europljana. Svjetski poznati infektolog iz Berlina otvoreno govori za 'Slobodnu', Slobodna Dalmacija. Date of publication 20. 4. 2020. Accessed 19. 9. 2020. https:// slobodnadalmacija.hr/vijesti/svijet/nemojmo-se-lagati-jako-se-dobro-zna-krivac-za-smrt-desetke-tisuca-europljana-svjetski-poznati-infektolog-iz-berlina-otvoreno-govori-za-slobodnu-1017279.

Mikac, Robert, Spevec. Davor. 2020. Response of the European Union to the COVID-19 crises. In: Keković, 
Zoran, Đorić, Marija, Poplović, Jadranka. (ed.). Security crisis in 21st century and how to manage them? Zagreb: Institute for Development and International Relations, Center for Risk Analysis and Crisis Management, Croatian Association for International Studies (in publishing).

Mikac, Robert. 2020. Kako Hrvatska upravlja krizama u kojima se našla? Politička misao. Date of publication 31.3. 2020. Accessed 3. 9. 2020. http:// politickamisao.com/kako-hrvatskaupravlja-krizama-u-kojima-se-nasla/ \#more-7893.

Nacional. 2020a. PLENKOVIĆ: "Hrvatska je, kao i Europa i svijet, u ratu protiv koronavirusa...". Date of publication 13. 3. 2020. Accessed 15. 9. 2020. https://www.nacional.hr/plenkovic-hrvatska-je-kao-i-europa-i-svijet-u-ratu-protiv-koronavirusa/.

Nacional. 2020b. PLENKOVIĆ: "Hrvatska je pobijedila covid-19, ova Vlada je pobijedila covid-19". Date of publication 26. 5. 2020. Accessed 14. 9. 2020. https://www.nacional.hr/ plenkovic-hrvatska-je-pobijedila-covid-19-ova-vlada-je-pobijedila-covid-19/.

net.hr. 2020. 'PITANJE JE KOLIKO ĆE HRVATA UMRIJETI TIJEKOM ZIME'; Lauc otkrio treba li razmišljati o oštrijim mjerama i priznao: 'Neke su bile pogrešne...' Date of publication 17. 9. 2020. Accessed 19. 9. 2020. https://net.hr/danas/hrvatska/pitanje-je-koliko-ce-hrvata-umrijeti-tijekom-zime-lauc-otkrio-treba-li-razmisljati-o-ostrijim-mjerama-i-priznao-neke-su-bile-pogresne/.

Novac.hr. 2020. Glas poduzetnika: 'Nedopustivo je da mjere ostanu ograničene na samo tri djelatnosti'. Date of publication 25. 5. 2020. Accessed 19. 9. 2020. https://novac. jutarnji.hr/aktualno/glas-poduzetnika-nedopustivo-je-da-mjere-osta- nu-ogranicene-na-samo-tri-djelatnosti/10339531/.

Novi list. 2020. Branko Roglić o Vladi samo sve najbolje: 'Mislim da su u krizi reagirali izvanredno'. Date of publication 8. 9. 2020. Accessed 20. 9. 2020. https://www.novilist.hr/vijesti/gospodarstvo/branko-roglic-o-vladi-samo-sve-najbolje-mislim-da-su-u-krizi-reagirali-izvanredno/.

N1. 2020a. Dražen Oreščanin: Zatvaranje teretana je alibi za loš rad Stožera. Date of publication 28. 8. 2020. Accessed 19. 9. 2020. http://hr.n1info.com/ Video/Info/a539216 /Drazen-Orescanin-Zatvaranje-teretana-je-alibi-za-los-rad-Stozera.html.

N1. 2020b. Zoran Milanović: Ustavni sud se prepao, ali to je ljudski. Date of publication 15. 9. 2020. Accessed 16. 9. 2020. http://hr.n1info.com/Vijesti/ a544718/Zoran-Milanovic-Ustavnisud-se-prepao-ali-to-je-ljudski.html.

Office of the National Security Council. 2020. Održana sjednica Vijeća za nacionalnu sigurnost. Accessed 17. 9. 2020. https://www.uvns.hr/hr/aktualnosti-i-obavijesti/odrzana-sjednica-vijeca-za-nacionalnu-sigurnost-1508.

Office of the National Security Council. 2018. Održana 4. sjednica Koordinacije za sustav domovinske sigurnosti. Accessed 13. 9. 2020. https://www. uvns.hr/hr/aktualnosti-i-obavijesti/odrzana-4-sjednica-koordinacije-za-sustav-domovinske-sigurnosti.

Raić Knežević, Ana. 2020. Ovo su ustavni suci koji se ne boje usprotiviti većini. Jučer protiv Stožera nije bilo prvi put. Telegram.hr. Date of publication 14. 9. 2020. Accessed 18. 9. 2020. https://www.telegram.hr/ politika-kriminal/ovo-su-ustavni-suci-koji-se-ne-boje-usprotiviti-vecini-danas-protiv-stozera-nije-bilo-prvi-put/. 
Schweller, L. Randall. 1994. Bandwagoning for Profit: Bringing the Revisionist State Back. International Security. (19) 1: 72-107. Doi:10.2307/2539149.

Tabak, Igor. 2020. Ostavka Krstičevića ujedno i kraj "domovinske sigurnosti"? Orbis.org. Date of publication 11. 5. 2020. Accessed 20. 9. 2020. https:// obris.org/hrvatska/ostavka-krsticevica-ujedno-i-kraj-domovinske-sigurnosti/

Taleb, Nassim Nicholas. 2009. Crni labud: Utjecaj krajnje nevjerovatnog. Zagreb: Jesenski i Turk.

Telegram. 2020. Istraživanje o koroni: 94 \% ljudi podržava Vladu, 63 \% misli da su nam mjere bolje nego u ostatku EU. Date of publication 28. 3. 2020. Accessed 18. 9. 2020. https://www.telegram. $\mathrm{hr} /$ politika-kriminal/istrazivanje-okoroni-94-ljudi-podrzava-vladu-63misli-da-su-nam-mjere-bolje-negou-ostatku-eu/.

tportal.hr. 2020a. Vlada okupila Znanstveni savjet za borbu protiv koronavirusa, evo tko je sve sudjelovao na sastanku s Plenkovićem. Date of publication 25. 3. 2020. Accessed 20. 9. 2020. https://www.tportal.hr/vijesti/ clanak/vlada-okupila-znanstveni-savjet-za-borbu-protiv-koronavirusa-20200325.

tportal.hr. 2020b. Đikić: Previše smo se zaigrali govoreći da smo pobijedili virus. Po stopi smrtnosti smo samo iza Bugarske, Rumunjske i Španjolske. Date of publication 16. 9. 2020. Accessed 21. 9. 2020. https://www.tportal.hr/vijesti/clanak/dikic-previse-smo-se-zaigrali-govoreci-da-smo-pobijedili-virus-po-stopi-smrtnosti-smo-sa- mo-iza-bugarske-rumunjske-i-spanjolske-foto-20200916.

tportal.hr. 2020c. Đikić: Prerano smo se otvorili i preagresivno propagiramo turizam, a mjere koje sada donosimo kasne. Date of publication 12. 7. 2020. Accessed 19. 9. 2020. https://www. tportal.hr/vijesti/clanak/dikic-prerano-smo-se-otvorili-i-preagresivno-propagiramo-turizam-a-mjere-koje-sada-donosimo-kasne-20200712.

Večernji.hr. 2020a. Oxford: Hrvatska ima najstrože mjere u Europi. Date of publication 26. 3. 2020. Accessed 21. 9. 2020. https://www.vecernji.hr/ vijesti/oxford-hrvatska-ima-najstroze-mjere-u-europi-iza-su-samo-srbija-i-sirija-1389281.

Večernji.hr. 2020b. Plenković objasnio što je kalkulirani rizik kojim je spašena turistička sezona. Date of publication 8. 9. 2020. Accessed 22. 9. 2020. https://www.vecernji.hr/ vijesti/plenkovic-projekcije-za-proljece-bit-ce-nesto-bolje-1429790.

Vuković, Vuk. 2020a. Vladine mjere za ekonomiju pokazuju da su potpuno izgubljeni u krizi. Index.hr. Date of publication 23. 3. 2020. Accessed 14. 9. 2020. https://www.index. $\mathrm{hr} / \quad$ vijesti/clanak/vuk-vukovic-vladine-mjere-za-ekonomiju-pokazuju-da-su-potpuno-izgubljeni-u-krizi/2167932.aspx.

Vuković, Vuk. 2020b. Ova kriza razotkrila je kako Hrvatska (ne) funkcionira. Index.hr. Date of publication 7. 4. 2020. Accessed 19. 9. 2020. http://www. poduzetnistvo.org/news/vuk-vukovic-pise-za-index-ova-kriza-razotkrila-je-kako-hrvatska-ne-funkcionira. 


\section{Pandemija COVID-19 i upravljanje krizom u Republici Hrvatskoj}

Sažetak Pandemija COVID-19 i kriza koja je zahvatila sve dijelove svijeta, sve industrije i poslovne procese, znatno su promijenili uobičajen način života svih ljudi, uveli društvo u "novo normalno" i nametnuli potrebu upravljanja krizom. Mnoge organizacije i države nisu spremne dočekale krizu te imaju velike posljedice. Cilj je ovog rada analizirati kako je Hrvatska reagirala na tu krizu s aspekta postojećega normativnog okvira upravljanja krizama i operativnih rješenja u praksi, istražiti ulogu Vlade Republike Hrvatske i njezinih čelnih ljudi u donošenju strateških odluka i tumačenju krize, kao i utvrditi u kojoj su mjeri korišteni sustavi domovinske sigurnosti i civilne zaštite u upravljanju krizom. Osim toga, cilje je rada zabilježiti određen broj kontradiktornosti, kontroverzija i paradoksa koji su se pojavili tijekom krize, kao i određena zapažanja koja mogu poslužiti za buduće analize i iskustva u procesu učenja.

Ključne riječi pandemija COVID-19, Hrvatska, krizno upravljanje, sustav domovinske sigurnosti, sustav civilne zaštite 
